\title{
REGULATIONS, MARKETS AND ECONOMIC EFFICIENCY: SUSTAINABLE DEVELOPMENT AND FOOD SECURITY
}

\section{Introduction}

Europe continues to be a "special space in the world" regarding achievements in human development. But this fact does not reduce the future challenges and responsibilities regarding its own population but also the overall (actual and future) impact on the rest of the world.

Food security, according to nowadays definition, derives its importance from the traditional fight to achieve the satisfaction of basic needs, with guarantees of "freedom from hunger". The European Community has been very successful in the food system improvements over the last decades, and one of the referential aspects in the system has been its Common Agricultural Policy (CAP). Indeed, CAP is considered to be an important example of technical intervention linked with reasonable governance able to provide a set of measures and policies with reference, and based in the market systems. In general, rules and norms, laws and regulatory systems have been crucial and do not substitute markets, they actually have a complementary but essential role in making the markets work better.

CAP policy is a global system with many objectives and it goes beyond production concerns. The CAP policy recognizes the multi-functionality of the food systems and agricultural production objectives, but at the beginning was very much focused on production increases, given the lack of autonomy in Europe regarding food needs. However, today, Europe and most of the industrialized countries have food surplus and/or food surplus capacity, which is very consistent with the structural model to be discussed (Carvalho 2013). In general, the food system has been very efficient, mainly in the most developed countries. However, based on gains in productivity and also gains in efficiency in economic production, questions on the sustainability and governance equations are now much more relevant than in the recent past.

Food policy, mainly as a public policy, was very successful and the regulatory efforts were able, in many different forms, to work well in connection with the markets. Many "regulations" can be seen as restrictions to production, but many of them can also be seen as the major method of providing the markets 
with the best conditions to perform well under certain conditions and objectives. Markets have always been at the centre of economic relations, and are dependent on the "institutional environment". Economic efficiency considerations have to consider at least three different aspects: production efficiency, consumption efficiency and governance/institutional efficiency. In many different situations, efficiency questions and analyses need to consider the existence of public goods, semi-public goods and a large set of situations were markets work poorly, such as the situations with significant externalities, scale/logistics problems, environmental conditions (natural and institutional), etc.

The example of CAP deserves attention at the world level for development purposes, mainly in regard to the enormous effort to support agriculture trying to avoid unfair trade procedures, which occurred in many situations, and correcting unfair trade impacts. The multi-functionality recognition of agricultural production activities, the social needs and income distribution policies along with the decoupled support measures have been crucial to promote regional development pursuing a lower negative impact in international terms (worldwide trade).

Global food supply, for the time being is not a problem, but hunger persists at very high levels (close to 1 billion people). Addressing possible solutions and understanding the phenomena is a very important research concern exploring and identifying possible contributions from science. In this paper efficiency questions are raised dealing with production, consumption and governance, "vis-á-vis" the food system and looking at possible science contributions.

\section{Referential concepts and hypothesis}

Economic development studies and knowledge, with its respective evolution, were prepared normally based on modelling economic systems and looking at comparisons of countries behaviour. Concepts and conceptual views and respective evolution are also very much related to the perception made about the real world system and respective evolution of thought, usually with a strong interaction with the most successful models. Hunger is an essential issue for every economic political structure aiming to achieve a sustainable development process, and belongs to the first set of objectives assumed by the United Nations (Millennium Development Goals) at the beginning of the $21^{\text {st }}$ century (in the year 2000, UN declaration).

The world situation regarding food availability and respective human social organization have been related and interdependent in such a way which is frequently not considered or even forgotten. However, since the beginning of the human civilization, food has always been a basic concern for human decisions and it is able to shape many of the structures developed, starting with the urbanization process. Indeed the world has been affected to the $4^{\text {th }}$ quarter of the $20^{\text {th }}$ century by lack of food, meaning a strong tension between food availability and population needs. With a systemic view and with an ecological perspective the human population has been very much "controlled" through "food 
availability" mainly in the $20^{\text {th }}$ century when human population growth entered into an exponential growth phase (the world had entered the $20^{\text {th }}$ century with around 1.5 billion people, and, at the end of the century, the world supported more than 6 billion people).

The FAO concerns (United Nations specialized Agency for Food and Agriculture) and mandate for feeding the world has been calling the attention to different food crises. One of the most important crises was in 1973, when Malthus theories were revisited. Indeed, at that time, Food Security concern received a new status and FAO first "gave the concept of food security a place in the international legal order..." (Boutros B. Ghali - Secretary General of the UN, speech at FAO 1996 summit) ${ }^{1}$. Indeed, since 1948 that security concerns have been on the Agenda of the UN, including food security. The Universal Declaration of the Human Rights affirmed that "Everyone has the right to a standard of living adequate for the wealth and well-being of himself and his family, including food...". Article 11 of the International Covenant on Economic, Social and Cultural Rights of 1966 called the attention to this fact when it affirmed the "right of everyone to be free from hunger". It is well recognized that "hunger" has been the essential issue in the international arena and that "food security" concept has been growing in substance with the time and development understanding that hunger and starvation, to be solved worldwide, have to be a multidisciplinary and multi-purpose objective and approach. However, it is also important to recognize that many times food is a "political issue" used in many directions and supported in many different disciplines and groups of interest, including science.

With the above description and brief discussion, what today is most comprehensive issue on the agenda is "a new terminology for hunger elimination objectives", which received a very basic, but internationally recognized definition of "food security". Indeed, one of the important achievements of the WFS -World Food Summit in 1996 was the approval of the definition of food security: "Food security exists when all people, at all times, have physical (social) and economic access to sufficient, safe and nutritious food which meets their dietary needs and food preferences for an active and healthy life" (FAO, 1996, with the term "social" added in 2002). According to Simon (2012), the WFP - World Food Programme offers the following definition: "A condition that exists when all people, at all times, are free from hunger" (WFP 2009 in Simon 2012).

In the previous work of the author, for example in Carvalho $(2014,2013$, 2011, and 1994) ${ }^{2}$ and the United Nations (1996) concepts and "official defini-

\footnotetext{
${ }^{1}$ Ghali speech at FAO summit (1996): "In 1973, when FAO first gave the concept of food security a place in the international legal order, we entered a new stage, for that made it possible a new universal level to define food policies, put in place strategies for action...".

${ }^{2}$ Carvalho in 1994 defines food security as: "Segurança Alimentar é obtida para uma determina da população referencial, quando é possível assegurar a todos os elementos dessapopulação o acesso em termos físicos e económicos a uma adequada alimentação" (Food security is achieved for a certain referential population when it is possible to guarantee to all members of that population the access, in physical and economic terms, to an adequate food intake).
} 
tion", food security means availability and access, in physical and economic terms, to enough and healthy food intake adequate to achieve a good nutritious status in a continuous and permanent way/path in time and space. The author considers five dimensions as the main set of factors to be considered in studying food security:

a) food availability;

b) access to food - including logistics, transformation, conservation, etc.;

c) utilization and consumption - including all variables related to food quality and nutritious values, but also all variables related to food consumption choices, such as education, habits and cultural background, etc.;

d) stability of the previous variables considered (and also stability of risks and uncertainty factors);

e) vulnerability of the system (including the resistance and resilience to external and internal shocks of the system).

From this point of view, assuming a multi-factor and cross-section analysis to better address the food security equation, in the following paper, it is necessary to explore some of the alternatives at hand that can be possible solutions to be implemented resulting from previous research and applied development policies. The main hypotheses to be considered are the following:

1. there is a surplus capacity in food production (Europe and OECD countries) that should be directed to promote capacity of other countries to produce and develop their food systems;

2. regulations in the food systems should be seen as major elements to support markets (MK) functioning, and not constraints to MK forces;

3. governance, in several forms, institutions and consumption economics, are other dimensions to be integrated in the global development model to understand the food system changes and dynamics (beyond supply growth);

4. demand constraints and structural changes in the economy should be addressed based on the "food balance equation";

5. the new "modern economy", based on non-tangible goods (virtual goods) and services, will also provide a new opportunity for the agribusiness activities;

6. health concerns and quality of life objectives will promote alternatives for food production and food consumption systems, which will show the advantages of the "food chain analysis" perspective;

7. value creation and sustainable development will be much more dependent on education and values coming from a well informed/educated society (with ethical considerations being included);

8. linkages of the food system with health and quality of life standards, will be crucial for development with sustainability considerations being one of the top priorities;

9. biological/organic/ecological food systems and the other food systems will evolve with a strong relationship between them, but certainly lower environmental impact is possible and desirable; 
10. institutional innovations, starting with strong governance and adequate food policy are needed at global but also at local level if hunger is to be reduced significantly.

Exploring all those hypotheses and statements and respective questions behind them in one paper is not feasible, unless the purpose is to show the linkages among them and start a broad discussion of the fundamentals of sustainable development and food security issues, which is the case. However, data analysis and the use of some proposed development models, with the study of some real cases, will provide the results necessary to derive important conclusions.

\section{Data analysis and facts}

The data presented will show the food supply per capita growth in several regions at global and local level, and respective absolute levels (Table 1 and Table 2) in the last 50 years. With this information technological changes are put in evidence, but indirectly also some demand constraints, because trade amounts are relatively small in aggregated levels, and not significant in per capita change measures. Other information showing the interface between production and population derived from FAO, made clear that the average availability of food per capita is above $2800 \mathrm{kcal}$ per day which is more than enough to feed the human population in the world in good conditions. However, hunger persists, showing our food system failure, which is mostly an institutional failure (not supply failure). The need for an integrated view, where regulations, markets and efficiency concerns can be part of a "system solution" (linking supply and demand, and demand and supply), is now clear.

Tab1e 1

Food supply per capita (kcal/capita/day) and total average growth rate in the period, per year

\begin{tabular}{lccccccc}
\hline & $\mathbf{1 9 6 1}$ & $\mathbf{1 9 7 1}$ & $\mathbf{1 9 8 1}$ & $\mathbf{1 9 9 1}$ & $\mathbf{2 0 0 1}$ & $\mathbf{2 0 0 7}$ & $\begin{array}{c}\text { 1961-2007 } \\
\text { (Geom. } \\
\text { Growth) }\end{array}$ \\
\hline World & 2200 & 2370 & 2512 & 2620 & 2722 & 2797 & 0.52 \\
USA & 2881 & 3058 & 3230 & 3509 & 3683 & 3748 & 0.57 \\
$\begin{array}{l}\text { European } \\
\text { Union }\end{array}$ & 3000 & 3212 & 3279 & 3377 & 3457 & 3465 & 0.31 \\
$\begin{array}{l}\text { LDCs } \\
\text { South }\end{array}$ & 1918 & 1968 & 1957 & 1966 & 2053 & 2136 & 0.26 \\
America & 2304 & 2457 & 2611 & 2637 & 2781 & 2885 & 0.49 \\
Asia & 1804 & 2026 & 2233 & 2441 & 2590 & 2668 & 0.85 \\
Africa & 2029 & 2111 & 2236 & 2298 & 2366 & 2461 & 0.42
\end{tabular}

Source: Faostat. 
Table 1 incorporates, in the last column, the growth rate for the whole period which shows a very fast rate of growth in food availability on average per capita above $0.5 \%$ per year and per person.

Table 2

Geometric growth rate of food supply per capita (kcal/capita/day)

\begin{tabular}{lccccc}
\hline & $\mathbf{1 9 6 1 - 1 9 7 1}$ & $\mathbf{1 9 7 1 - 1 9 8 1}$ & $\mathbf{1 9 8 1 - 1 9 9 1}$ & $\mathbf{1 9 9 1 - 2 0 0 1}$ & $\mathbf{2 0 0 1 - 2 0 0 7}$ \\
\hline World & 0.75 & 0.58 & 0.42 & 0.38 & 0.45 \\
USA & 0.60 & 0.55 & 0.83 & 0.49 & 0.29 \\
$\begin{array}{l}\text { European } \\
\text { Union }\end{array}$ & 0.65 & 0.21 & 0.30 & 0.23 & 0.04 \\
LDCs & 0.26 & 0.04 & -0.05 & 0.43 & 0.86 \\
South & 0.65 & 0.61 & 0.10 & 0.53 & 0.62 \\
America & 1.16 & 0.98 & 0.89 & 0.60 & 0.49 \\
Asia & 0.39 & 0.58 & 0.28 & 0.29 & 0.66 \\
Africa & & & &
\end{tabular}

Source: Faostat, 2010 data and authors calculations.

The figures below are quite elucidatory, but put in evidence that supply growth and even per capita growth availability of food did not solve the problem.

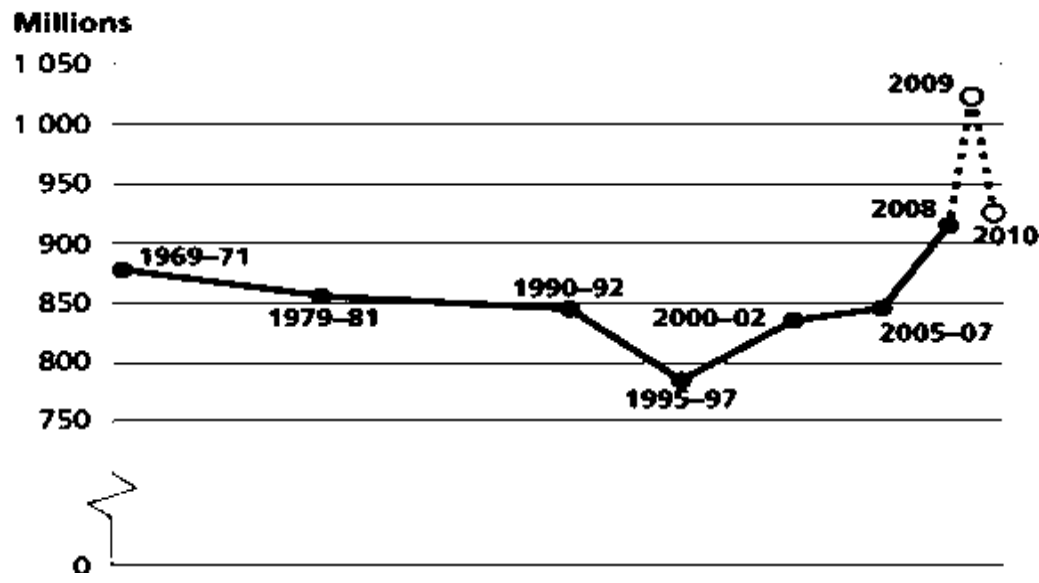

More: Figures for 2009 and 2010 are estimated by FAO with input from the United States Department of Agriculture, Economic Research Service. Full details of the methodology are provided in the technical background notes (available at www.fao.org/publication/sofi/en/).

Fig. 1. Number of undernourished people in LDCs

Source: FAO. 


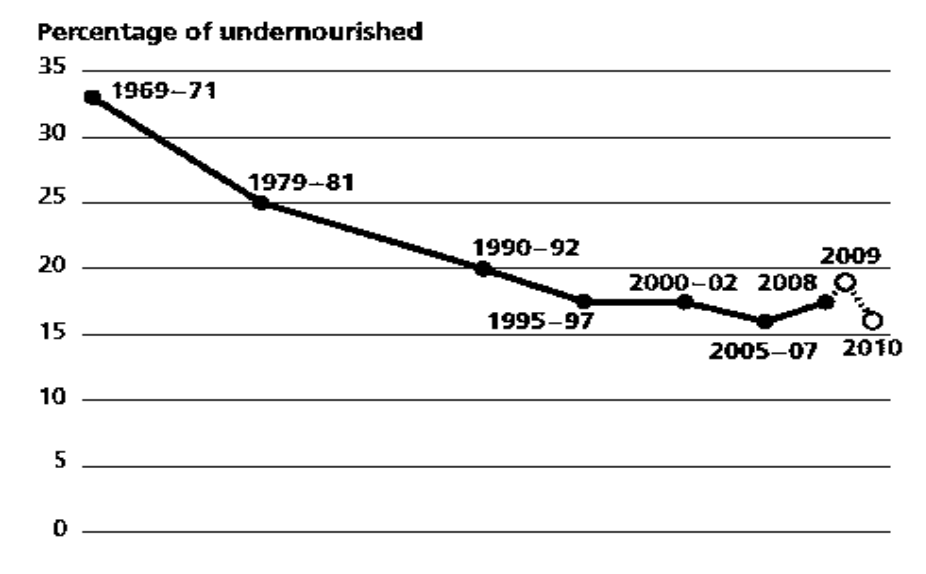

Fig. 2. Proportion of undernourished people in LDCs

Source: FAO.

The number of people suffering from hunger is quite stable - between 800 millions and 1 billion - in the last half of the century, but with significant improvements in relative terms up to mid-nineties. That is, in the last 10 to 20 years there were no relative improvements at all. However, when the analysis moves to food consumption in relation to certain types of foods, like cereals and meat and/or milk, it is quite clear that Engel's curve rational will appear showing that after a certain level of income no more consumption increase is expected per person. Adding to this the stabilization of people/population in many developed areas (no growth at all, or even decrease), such as Europe, the conclusion will turn out to be that consumption levels will stabilize based on local markets.

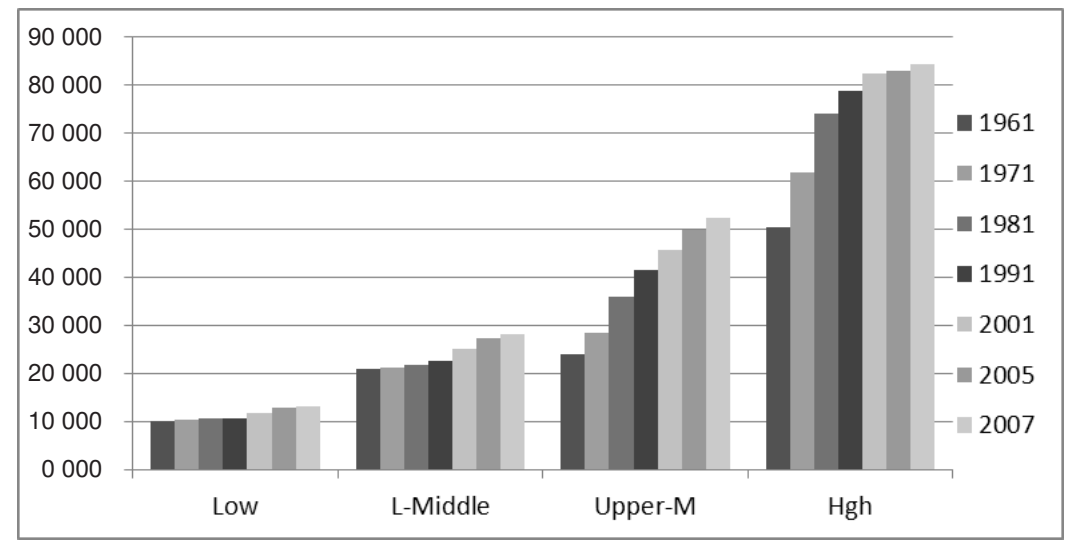

Fig. 3. Meat Supply (kg/capita/year) by country group

Source: Faostat (2011) basic data and author's elaboration. 


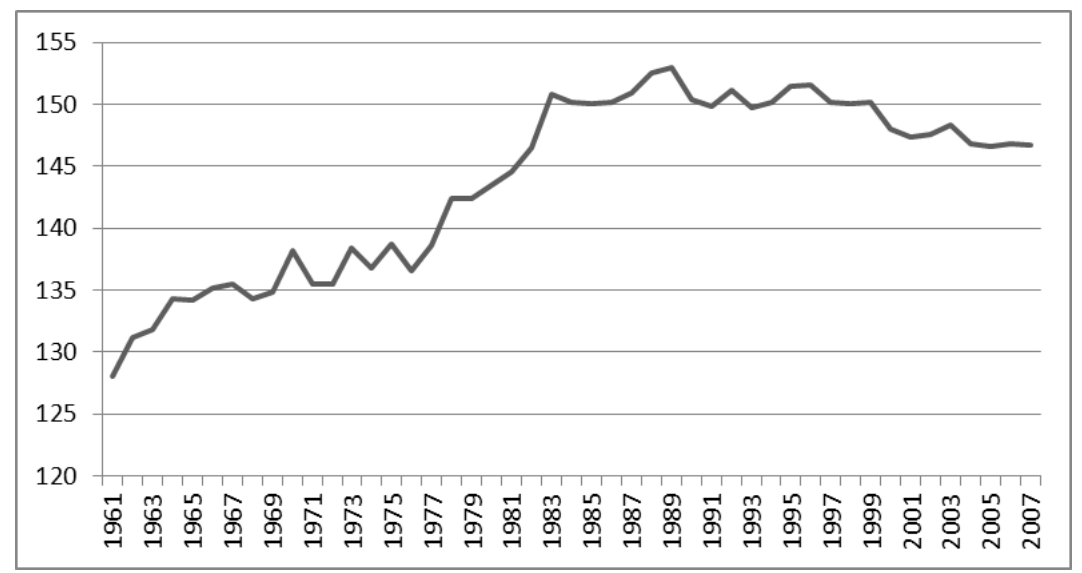

Fig. 4. World food supply of cereals (kg/capita/yr)

Source: Faostat, 2011 and author calculations (based on the 3 main cereals: wheat, rice and maize).

Figures 3 and 4, for meat and cereals, show the consumption economic principle of marginal decreasing utility for any consumption good considered normal and/or basic good, where permanent increases in income produce lower and lower marginal utility for consumers. When the exercise is done comparing countries at different income levels, the decreasing marginal utility effect appears. Even at world level - Fig. 4 - the evidence shows that in per capita terms cereals consumption is not increasing any more in per capita average. Again, demand constraints are quite clear with this type of results, showing decreasing marginal utility with income growth and higher levels of food consumption, or even tendency to decrease in basic foods, such as cereals, because diversity in food consumption is expected and desirable.

\section{Observed structural changes and case studies examples}

Changes over time are expected in the economy, desirable most of the time, and can be designed to occur in certain patterns which have been identified by those studying and trying to understend the process of economic development. For example, the agro-related activities are supposed to decrease its importance in the economy (at least apparently...) when measured in terms of its contribution to the National Output (GNP - gross national product, and GDP - gross domestic product). Sector shares importance in the economy and respective evolution of agricultural but also industry activities are decreasing, with relative importance of services growing. Figures 5 and 6 illustrate those structural changes over time. 


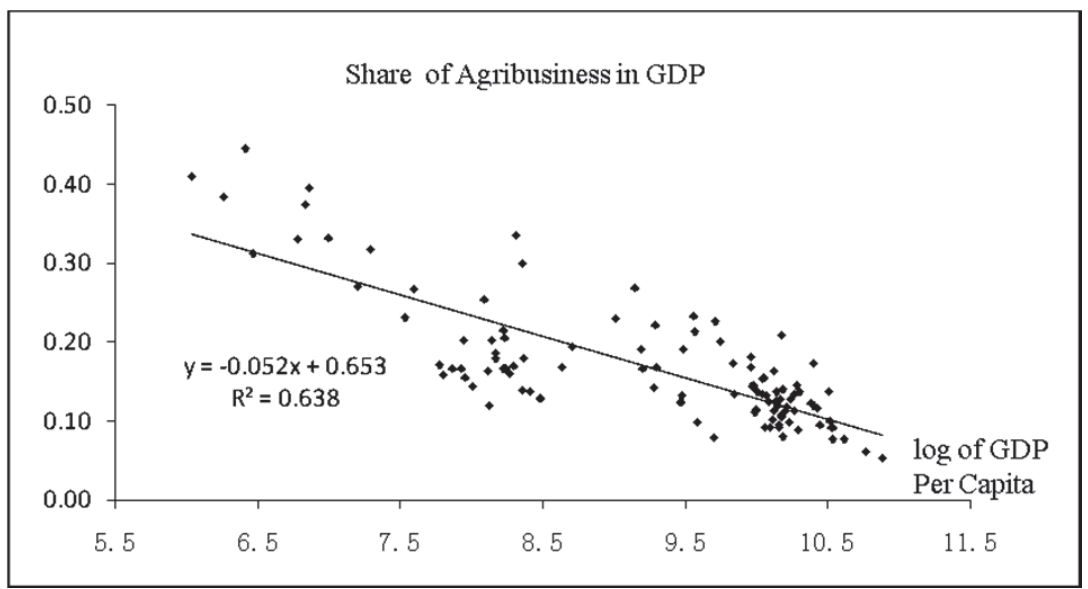

Fig. 5. Share of agribusiness in GDP for OECD countries in 2000

Source: https://www.iioa.org/conferences/19th/papers/files/442.pdf - p. 6 in Fachinello, 2014.

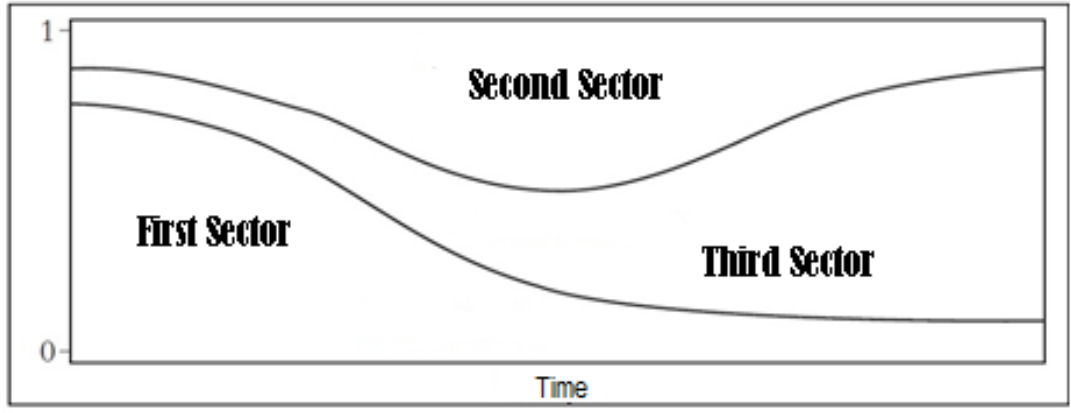

Fig. 6. Dominant sector structure in the development process: agriculture - industry and services (first, second and third sectors)

Source: Kruger (2008, p. 333).

The evidence shows the changes in tendencies over time, keeping in mind that agro-related activities are seen here as the ones related with production and transformation, but not all the other co-related activities classified in services.

\section{The need for development models: some proposals}

To better understand changes and processes of change, the suggestion is to use development models already in use in the literature, and also address connected evolution of concepts, such as the one already discussed, namely the food security concept.

The choice made is based on three different approaches, but all will be used for an integrated discussion. The referential models are the following: 
a) World Food Security Equation (WFSE);

b) Induced Change and Innovation Model (ICI model);

c) Demand Constraints Rational.

The first one, is a structural development model, which states that countries move through 4 different phases (Mellor and Johnston, 1984, propose 3 stages, and the author in Carvalho et al. 2011 points out 4 different stages) going from a stage of equilibrium with nature (ecological phase) to a long period of lack of food (with demand growing faster than supply of food - second phase), to a third shorter period - one of surplus, with supply growth greater than demand and, finally, to a new relative equilibrium phase with supply and demand matching behaviours (a full market with good institutional and policy environment).

The second one, is based on the traditional Induced Innovation Model (Hayami and Ruttan, 1973 and 1985) and proposed derived model from Carvalho (2004) where the main rationale is to assume that changes occur accordingly with economic forces, where natural resources, technology, institutions and cultural background are all connected, and where markets and governments play a determinant role.

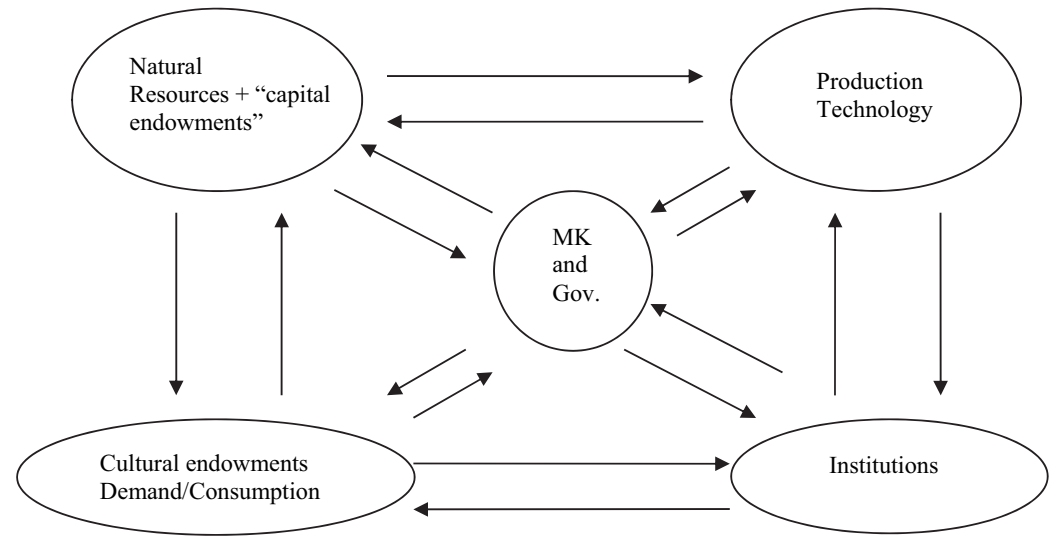

Fig. 7. Induced changes and innovation model

Source: Carvalho B.P. de (2004) and author elaboration.

The third one, links immediately with both previous models and the discussion moves from a dual economy perspective, from supply and demand sides, to a more holistic view where production is "taking over demand" that is, we are considering that production is indeed any activity where, from more than one input, with a certain technology we obtain present or future utility (we obtain a product/output, tangible or not, that has utility, present or future utility). Carvalho (2014) discusses this perspective where demand (and/or production of utility) is indeed the goal of any activity. Demand (production of utility) is the last step in the "production chain" which means demand is driving the economic world every day, with more intensive presence, since the world production capacity, in 
general, is now moving far beyond the human capacity to consume. The implications of this situation are now putting much more responsibility on the human choices, education and value system of our society. What is the goal and what we want to consume for an improved quality of live and well-being. The agricultural sector, very much linked with services from nature and environment, is now facing new challenges and opportunities. On food product markets, some new demands - such as the one based on biological/organic/ecologic production systems - will be growing, but quality of life will demand other services, landscape dimension, tourism, health needs, cultural traditions and other areas derived from services from nature will also be necessary. All these dimensions that are now being considered are very much linked to the multi-functionality recognition of agricultural activities, where the social dimension cannot be forgotten. The occupation of free time, the creation of jobs and social cohesion are clear contribution today and will be even more important in the future.

\section{Food System Case Study: Portugal example in Europe/an overview}

Portugal example in Europe can serve to test how useful the discussed models can be to explain the recent evolution "vis-á-vis" the expected structural changes, the European Union integration impact looking at the Induced Change model rational and combining perspectives, taking also into consideration the "demand constraints rational".

In economic terms, it is a well known fact that agricultural output share in the gross domestic national output is supposed to decrease, almost as fast as the economy can show high rates of economic general growth. However, what we can observe in the last decades is also a decrease in industrial share in the economy, with clear advantage for services.

Table 3

Sectors relevance - share of GDP $(\%)$

\begin{tabular}{|c|c|c|c|c|c|c|c|c|}
\hline PORTUGAL & IMP.SECTOR & \multicolumn{7}{|c|}{ \% GDP } \\
\hline & & 1954 & 1974 & \multicolumn{2}{|c|}{1995} & 2002 & 2011 & $\begin{array}{c}\text { Dif. } \\
2002- \\
-2011\end{array}$ \\
\hline 1'aSERIE & AG+FISH+INDUST. & 55 & 40.6 & \multicolumn{2}{|c|}{27.4} & & & \\
\hline \multirow[t]{6}{*}{ 2aSERIE } & AG+FISH+INDUST. & & & \multicolumn{2}{|c|}{21.4} & 17.3 & 14.5 & -2.8 \\
\hline & & & & 1aSERIE & 2aSERIE & & & \\
\hline & AGR+For & 29 & 11.7 & 6 & 4.9 & 2.8 & 1.9 & -0.9 \\
\hline & Fish & & & & & & & \\
\hline & INDUSTRY & 26 & 29 & 21.4 & 16.6 & 14.6 & 12.6 & -2 \\
\hline & ENERGY & 1.4 & 1.7 & 3.6 & 2.6 & 2.4 & 3.2 & 0.8 \\
\hline
\end{tabular}

Source: BP and INE in Eugenio Rosa (2013). 
The data in Table 3 is quite important in terms of showing changes over time and, depending on many assumptions, it is important to compare those changes with other countries to understand how different or similar those changes have been (patterns identification).

Table 4

The industrialization - \% GDP of Industry+Energy sectors in selected countries in Europe

\begin{tabular}{lcccc}
\hline & $\mathbf{2 0 0 0}$ & $\mathbf{2 0 0 9}$ & $\mathbf{2 0 1 0}$ & $\mathbf{2 0 0 9 - 2 0 0 0 ~ D i f . ~ \% ~}$ \\
\hline EU & 22.4 & 18.1 & 18.7 & -4.3 \\
Germany & 25.3 & 22.4 & 23.8 & -2.9 \\
Portugal & 20.4 & 16.8 & & -3.6 \\
Ireland & 34.1 & 26.4 & 25.9 & -7.7 \\
Spain & 20.9 & 15.4 & 15.9 & -5.5 \\
France & 17.8 & 12.5 & & -5.3 \\
Greece & 13.9 & 13.4 & 13.6 & -0.5
\end{tabular}

Source: Eurostat in Eugenio Rosa (2013).

Table 4 allows comparisons but shows that industrial sector (+energy) is not increasing its share but indeed loosing importance in the economy in general. This can be seen also as expected, because consumption patterns are also changing, and Portugal behaved in similar terms as others.

From the consumption point of view, and looking into habits and cultural background, it is important to compare the country situation before looking into the specifics of the agribusiness sector. It is a well known fact that food consumption depends on income, but beyond a certain income level, consumption tends to stabilize or even to decrease in many food products, with more diversified diets.

However, cultural habits/endowments, and natural resources are also important factors with impact on the production and consumption systems (interacting and inducing some behaviours which differ from others).

The data for other European countries is given in annex 1. Poland, for example, is with 3392 calories per day per capita which is very close to the United Kingdom and other East European countries. The UK, for example, is not increasing its consumption in caloric terms for the period considered, and probably, for some other countries no increases will be observed in the near future. However, only two countries achieved the levels above 3700 kilocalories, i.e. Austria and Belgium. Most countries will probably reach the maximum between 3500 and 3700 kilocalories, where Portugal, France, Germany, Italy and others have already reached the level. 
Table 5

Average kcal available per person per day in European Member States - 2007-2009

\begin{tabular}{llll}
\hline \multicolumn{1}{c}{ European Member States } & & Years & \\
\hline & 2007 & 2008 & \\
$>\mathbf{3 7 0 0}$ kcal per person per day & & & 3800 \\
Austria & 3816 & 3826 & 3721 \\
Belgium & 3736 & 3751 & \\
$>\mathbf{3 5 0 0}$ and $<\mathbf{3 7 0 0}$ kcal per person per day & & & 3661 \\
Greece & 3637 & 3656 & 3637 \\
Luxembourg & 3599 & 3592 & 3627 \\
Italy & 3628 & 3612 & 3617 \\
Portugal & 3582 & 3614 & 3617 \\
Ireland & 3564 & 3588 & 3549 \\
Germany & 3552 & 3537 & 3531 \\
France & 3520 & 3598 &
\end{tabular}

Source: DGS - Direcção Geral de Saude (2013).

Table 6

Fruit and vegetables average quantities available per capita and per year

\begin{tabular}{lccc}
\hline \multicolumn{1}{c}{ States of the EU } & Years & \\
\hline & 2007 & 2008 & 2009 \\
$\mathbf{3 0 0 ~} \mathbf{~ k g / y e a r ~}$ & & & \\
Greece & 388.5 & 360.2 & 385.6 \\
Portugal & 291.2 & 279.7 & 313.1 \\
Italy & 300 & 284.1 & 312.4 \\
Malta & 307.4 & 311.6 & 305.6 \\
$>\mathbf{2 0 0}$ and $<\mathbf{3 0 0} \mathbf{~ k g / y e a r}$ & & & \\
Luxembourg & 283 & 291.2 & 277.3 \\
Ireland & 225.6 & 244.1 & 244.3 \\
Denmark & 208.9 & 210.5 & 235.4 \\
Spain & 236.5 & 247.6 & 231.8 \\
Austria & 245.8 & 259.9 & 228.6 \\
Romania & 209.5 & 229.2 & 226.6 \\
Cyprus & 230.4 & 205.4 & 225 \\
\hline
\end{tabular}

Source: DGS - Direcção Geral de Saúde. 
Looking into Europe, it is a well known fact that there are differences in food habits among countries, and indeed Portugal has, probably, one of the diets considered most favourable to good health practices. Recently, introducing a clear institutional innovation - UNESCO classification of "Intangible Cultural World Heritage" - established the recognition of the Mediterranean Diet (2010-2013). Portugal is one of the countries recognized, belonging to the group. One of the characteristics defining the Mediterranean Diet is the high consumption of fruit and vegetables.

Table 6 provides evidence that geographic localization in the Mediterranean area also produces a usual impact in terms of higher consumption of fruit and vegetables. Greece, Portugal, Italy and Malta are the ones with higher consumption levels (more than $300 \mathrm{~kg}$ per year per capita). Countries like Poland and Germany are located in consumption terms below $200 \mathrm{~kg}$ per year per capita. Income is certainly important, but there are other variables which make the impact much higher.

Table 7

Per capita consumption and degree of food self-sufficiency in Portugal

\begin{tabular}{|c|c|c|c|c|c|c|c|c|}
\hline & \multicolumn{8}{|c|}{ Capitação Bruta/Per capita consumption } \\
\hline & \multicolumn{2}{|c|}{$1980 / 1982$} & \multicolumn{2}{|c|}{$1990 / 1992$} & \multicolumn{2}{|c|}{$2000 / 2002$} & \multicolumn{2}{|c|}{$2006 / 2008$} \\
\hline & $\mathrm{kg} /$ year & GAA \% & $\mathrm{kg} /$ year & GAA \% & $\mathrm{kg} /$ year & GAA \% & $\mathrm{kg} /$ year & GAA $\%$ \\
\hline $\begin{array}{l}\text { Cereais / } \\
\text { Cereals }\end{array}$ & 143.4 & 27.8 & 144.9 & 47 & 154 & 33.1 & 152 & 26.9 \\
\hline Trigo/Wheat & 91.2 & 37.1 & 99.7 & 36.1 & 109 & 17.7 & 108 & 11.5 \\
\hline Arroz/Rice & 20.7 & 63.1 & 23.2 & 59.35 & 25.3 & 52 & 25.3 & 53 \\
\hline Milho/Maize & 12.9 & 16 & 12.5 & 47.2 & 11.9 & 43.2 & 10.6 & 29.2 \\
\hline $\begin{array}{l}\text { Raizes +tub/ } \\
\text { Roots + tubers }\end{array}$ & 139.8 & 94.2 & 154.4 & 64.8 & 103.7 & 57.8 & 91.7 & 58.7 \\
\hline $\begin{array}{l}\text { Legumi.Secas/ } \\
\text { Dry legumes }\end{array}$ & 3.8 & 80.4 & 6.2 & 49.2 & 4.1 & 16.2 & 4.3 & 10.01 \\
\hline Prod.Horticolas & 85.7 & 148.3 & 70.1 & 178.8 & 95 & 157.9 & 114.8 & 166.4 \\
\hline Frutos/Fruit & 61.5 & 100.1 & 103.6 & 88.4 & 128.7 & 72.7 & 120.8 & 74.6 \\
\hline Azeite/Olive oil & 4 & 101.6 & 3.5 & 104 & 5.8 & 47.2 & 6.2 & 57.6 \\
\hline $\begin{array}{l}\text { Vinho+derivados } \\
\text { /Wine+ } \\
\text { derived products }\end{array}$ & & & 62.2 & 129.1 & 47.7 & 118.2 & 43.6 & 114.8 \\
\hline Carne+miudezas & 51 & 99 & 69.9 & 88.3 & 91.7 & 78.9 & 94.9 & 69.6 \\
\hline $\begin{array}{l}\text { C. de Bovin/ } \\
\text { Bov.Meat }\end{array}$ & 12.9 & 96.2 & 16.7 & 76.8 & 16.3 & 60.4 & 18.5 & 52.2 \\
\hline $\begin{array}{l}\text { C.de suíno/ } \\
\text { Pork Meat }\end{array}$ & 12.6 & 100.7 & 20.4 & 86.7 & 31.4 & 70.6 & 32.8 & 51.3 \\
\hline $\begin{array}{l}\text { C. de Aves/ } \\
\text { Chicken meat }\end{array}$ & 16.3 & 100 & 20 & 101.3 & 30.7 & 96.7 & 31.5 & 93 \\
\hline $\begin{array}{l}\text { Ovino+Caprino/ } \\
\text { Sheep+Goat meat }\end{array}$ & 2.5 & 100 & 3.9 & 92.4 & 3.5 & 70.4 & 2.9 & 79.8 \\
\hline
\end{tabular}

Source: Ministry of Agriculture. 
Looking into the specifics of the food balance equation for Portugal, which should be achieving a similar behaviour to other countries in Europe belonging to the third or fourth phase, using Mellor and Johnston (1984) classification and/ or Carvalho (2013) classification, where consumption does not improve for food globally (that is, it is already not increasing in average with income growth, and there is no population growth) but where agriculture output is growing, the final result is also dependent on other variables, and in the last decades changing very much, dependent on the European Common Agricultural Policy (CAP). Table 7 provides data, able to bring a new perspective on the country situation regarding autonomy and dependence/interdependency in food availability (GAA - degree of self-sufficiency in food availability).

Globally, looking at the evolution in consumption per capita terms and looking also at the changes up to 1980-82 and after the EU integration (1986), what can be concluded, basically regarding consumption and dependency upon outside, is that there was the consumption growth up to 1990-92 and/or 2000/2002, with stabilization afterwards and/or slight decreases in levels of consumption, but a clear growth, regarding dependency upon outside. Looking at the position, degree of autonomy in production/consumption, up to 1980-82 and/or 1990-92 (considered before the EU) and afterwards in 2006-2008 (before food crises, and economic crises), considered after the EU, can be summarized like that (Table 8):

Table 8

Self-sufficient rates in Portugal, before and after the EU integration, measured in \% of local production in regard to consumption. GAA\% - degree of self-sufficiency

\begin{tabular}{lcc}
\hline & Before the EU - GAA \% & After the EU - GAA\% \\
\hline Cereals & 47 & 27 \\
Wheat & 37 & 11.5 \\
Rice & 63 & 53 \\
Maize & 47 & 29.2 \\
Roots and Tubers & 94.2 & 58.7 \\
Horticutural+Fruit & 178.8 & 166.4 \\
Bovine Meat & 96.2 & 52.2 \\
Pork Meat & 100.7 & 51.3 \\
Chicken Meat & 100 & 93 \\
Ovine+Goats & 100 & 79.8 \\
Milk & 100 & 106.2 \\
Fish & 102.1 & 41.1
\end{tabular}

Source: Data from Table 7.

Some obvious conclusions can be derived, starting with growth in dependency upon outside, mainly from the EU. The next question is to look at the sector behaviour in terms of growth and trade. What will be expected in a sound 
and wealthy dependency growth upon outside, mainly the EU as a result of the EU integration, will be to have greater relevance from imports in particular goods with no comparative advantages, but also specialization and capacity to improve substantially the export capacity.

To try a quick answer to the above question, let us look first at the global economy relationships, mainly the balance of trade, and after that at the food sector behaviour.

Table 9 shows a relative short data trend, but enough to elucidate the main drivers of the economy. Portugal had a tremendous growth period up to 2000, the first 15 years of the EU integration, with great infrastructural investments, but with clear tendency for negative trade balance which achieved very high levels in 2000, but good growth rates in exports and imports. The recent crisis in regard to the balance of payments and debts, is now putting a strong pressure on the economy, forcing net trade balances which occurred for the first time in 2013 (after more or less 70 years of the country history - last time the net trade balance happened during the World War II in 1943).

Table 9

\section{Portugal Trade Balance - millions of euros}

\begin{tabular}{cccccc}
\hline Year & \multicolumn{2}{c}{ Exports } & \multicolumn{2}{c}{ Imports } & Trade Bal. \\
\hline & Goods & Services & Goods & Services & Net Trade Balance \\
1996 & 19322 & 6077 & 26897 & 5002 & -6499 \\
2000 & 27209 & 9830 & 43641 & 7622 & -14225 \\
2013 & 47653 & 20564 & 54733 & 10639 & 2845
\end{tabular}

Source: Banco de Portugal in PorData, 2013.

It is not the time and place to discuss the European crisis and Portugal reaction to it, but to face the numbers and look at the contribution of the agricultural sector to the economy, especially in regard to the "dependency" equation which is clearly rising as expected with integration, but always forcing new systems equilibrium. In regard to food security dimension, the concern for food sector dependency and interaction within Europe and outside Europe, goes beyond economics. There are concerns about national security, safety, risks and vulnerability among other dimensions. However, globally, and in some food systems the country is improving substantially.

What can be seen is a very high growth rate in trade areas, imports and exports. However, export growth is improving at higher rates for the agribusiness sectors in a very impressive way, allowing the conclusion that those activities are contributing strongly to improve the trade balance and balance of payments. Table 8, above, also provided a confirmation of the success of the agribusiness sector in terms of openness to the international trade, showing the comparison with the overall economy but also to the tradable goods. 
Table 10

Comparative growth rates for the Agroforestry and Fisheries Sector and the economy in the $2000-2011$ period (\% in current prices)

\begin{tabular}{lcc}
\hline & Imports & Exports \\
\hline Agriculture & 4.0 & 10.9 \\
Fisheries & 4.3 & 6.1 \\
Food, Beverage and Tobacco Industries & 4.8 & 8.0 \\
Forestry & -1.8 & 5.0 \\
Forest Industries & 1.6 & 4.4 \\
Agri-food Sector & 4.6 & 8.2 \\
Forest Sector & 1.1 & 4.4 \\
Agroforestry and Fisheries Sector & 3.8 & 6.2 \\
Economy - Goods & 2.3 & 4.0 \\
Economy - Goods and Services & 2.6 & 4.6
\end{tabular}

Source: GPP estimates from National Accounts, INE.

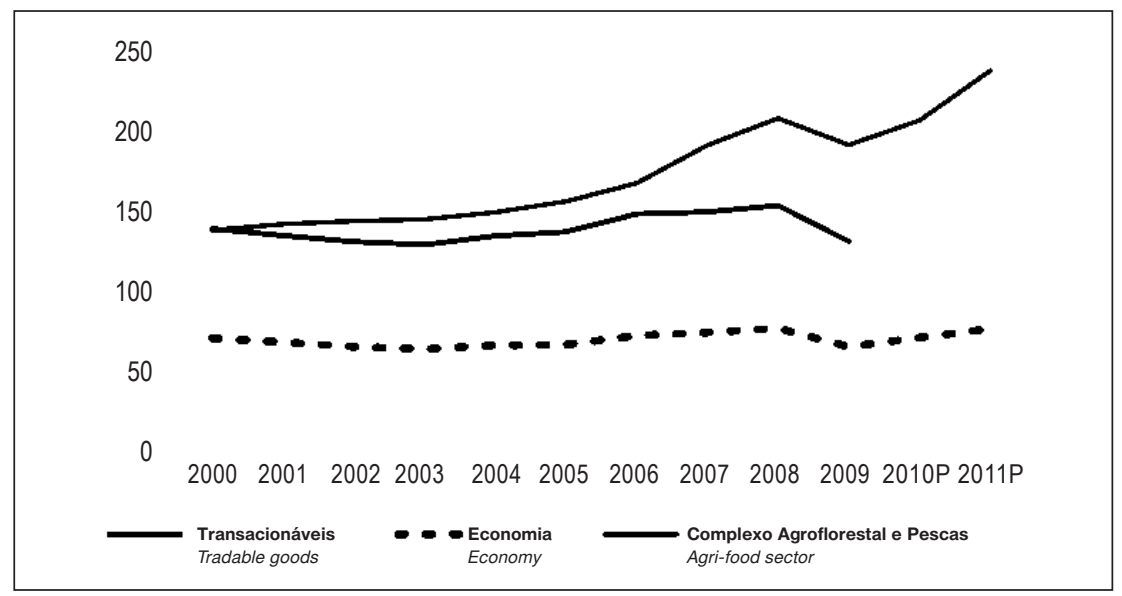

Fig. 8. Degree of Openness of the Agri-food sector and Tradable Goods 2000-2011 (\% current prices)

Source: GPP from National Accounts, INE.

With all those results, the next question will be how the agribusiness sector can be seen worldwide, and how significant it is in the economy of Portugal nowadays. The recent good results in growth, global output growth, after many years of relative low increases (anaemic behaviour), adding to some good leadership and crises in the economy globally, have made this sector very attractive and fashionable for the first time in many years. To put in evidence the relative importance of the country worldwide in terms of agribusiness activities, a selection of significant facts was identified, such as: 
1. cork sector $-1^{\text {st }}$ in the world in production and processing;

2. tomato industry $-4^{\text {th }}$ in world exports and $2^{\text {nd }}$ in Europe exports in 2012, after the USA, China and Italy. "Top yields" - the highest average productivity in Europe and $3^{\text {rd }}$ in the world;

3. paper pulp - the $6^{\text {th }}$ biggest producer in Europe and $13^{\text {th }}$ in paper, pulp and board industry (Eurostat data in Aicep - Portugal - 2012);

4. rice - production and consumption relevance (10\% "top yields" $-1^{\text {st }}$ in consumption per capita in Europe);

5. maize (modern systems are achieving average yields at the highest levels in the world);

6. horticulture and fruit - the case of pear "Rocha" deserves reference (the $6^{\text {th }}$ biggest producer in Europe for pears);

7. wine - traditionally among the top 10 biggest producers;

8. olive oil - sector recovering form the past with new technology and great expansion in production and exports (for example achieving around $40 \%$ of all imports from Brazil). Relevance also in biological production alternatives in traditional systems.

Considering the relative position in Europe, and in the world, a small/medium country with 10 million people, such as Portugal, shows in agribusiness, an important presence in many sectors. Indeed, it is surprisingly bigger than expected and with strong internationalization (openness). The models discussed and respective rationale provided opportunities to better understand changes and help to derive important conclusions for policy makers.

\section{Main conclusions and new opportunities for Europe}

Portugal was almost $100 \%$ self-sufficient for the most part of the food products, with clear deficit only in cereals before the EU entry in 1986.

The EU relations are complex (more dependent and/or interdependent today), but in the last years the agro-system has been able to react in many sectors linked to technology changes and/or the international markets. The "openness" of the sector is impressive.

All the main important chains in the agribusiness are linked to technological changes and the international markets and/or do not face any demand constraints.

The country is very well adapted to good performances in crops and food systems where the eco-systems play their role in competitive terms (with high productivity rates in tropical, sub-tropical crops and/or from Mediterranean origin) and no demand constraints are "binding".

Consumption patterns and their changes are also very much in line with natural resource base and production activities (induced model test, for production and consumption). Europe is on the $4^{\text {th }}$ phase in the Food Balance Equation - (WFSE model) with "no need" to improve global production.

The big challenges are around "Quality" and Efficiency (including lower environmental impact in production activities) creating value, but certainly mainly in new forms, markets and services. 
Country list for consumption in kilocalories per capita per day

\begin{tabular}{|c|c|c|c|}
\hline \multicolumn{4}{|c|}{$>3000$ and $<3500$ kcal per capita per day } \\
\hline Romania & 3442 & 3546 & 3487 \\
\hline Lithuania & 3487 & 3514 & 3482 \\
\hline Hungary & 3491 & 3495 & 3477 \\
\hline Malta & 3444 & 3428 & 3438 \\
\hline United Kingdom & 3453 & 3453 & 3432 \\
\hline Poland & 3389 & 3363 & 3392 \\
\hline Denmark & 3393 & 3370 & 3378 \\
\hline Czech Republic & 3244 & 3466 & 3305 \\
\hline Slovenia & 3221 & 3268 & 3275 \\
\hline Netherlands & 3266 & 3277 & 3261 \\
\hline Finland & 3229 & 3218 & 3240 \\
\hline Spain & 3269 & 3232 & 3239 \\
\hline Estonia & 3121 & 3131 & 3163 \\
\hline Sweden & 3096 & 3123 & 3125 \\
\hline \multicolumn{4}{|c|}{$<3000$ kcal per capita per day } \\
\hline Latvia & 2949 & 2993 & 2923 \\
\hline Slovakia & 2838 & 2866 & 2881 \\
\hline Bulgaria & 2775 & 2802 & 2791 \\
\hline Cyprus & 2644 & 2665 & 2678 \\
\hline
\end{tabular}

Health, quality of life concerns and agribusiness/nature based activities are new "windows" for value creation.

The chain value approach, with special concern for the share value distribution along the chain, deserves a lot of attention and call for institutional innovation regarding markets functions and better governance. Transparency, information access (transaction costs) and negotiation power balances are key aspects to be taken into consideration.

New markets can be created, some of them in the European zone, with new products and "consumption forms", including in the traditional and nondifferentiated products, mainly in the Eastern regions, where food consumption can still grow significantly.

This production growth should be well connected with consumption growth, but expansion should be also driven by quality and efficiency considerations, and value creation alternatives linked with services and the multi-functionality "deals" of the agriculture related activities (eco-tourism, quality of life, climate change and environmental impacts, etc.). A systemic perspective is a necessary condition. 
New demands, new niche markets and health concerns will be crucial, such as the case of the "biological/organic/ecological" production systems.

The overcapacity in the food sector in OECD countries should be turned into forms of support for LDCs (mainly tropical and/or sub-tropical countries) based on "knowledge" capacity transfer (not necessarily technological transfer which is not adapted, in most cases, to local conditions), with institutional innovation, giving priority to the ability of promoting sustainable development and empowerment of the food systems.

\section{Literature:}

1. AICEP. Portugal Global. Perfil do País. Agência para o Investimento e Comércio Externo de Portugal. Lisboa 2012.

2. Banco de Portugal. Statisticalnumbers. Data online in Pordata.

3. Carvalho B.P. de: Dualismo e Desenvolvimento na Agricultura. Revista de Economia Rural 23(1): 41-54, Brasília. Brazil 1985.

4. Carvalho B.P. de: Cooperação e Desenvolvimento: Oportunidades e Desafios para o Séc. XXI. (Cooperation and Development: Opportunities and Challenges for the $21^{\text {st }}$ century). SEDGES 10(3). Série de Estudos de Desenvolvimento e Gestão de Sistemas. CIAT - CD/ISA/UTL. Center for Tropical Ag. Research - Cooperation and Development. Instituto Superior de Agronomia - Universidade Técnica de Lisboa 2004.

5. Carvalho B.P. de, Costa, D. and Leite I.: Global Food Outlook: Global challenges and local solutions. IFAMA, $21^{\text {st }}$ Annual World Forum and Symposium Frankfurt, Germany 2011.

6. Carvalho B.P. de: Demand constraints and technical change. PhD Thesis. University of Minnesota, St. Paul/Minneapolis. USA 1989.

7. Carvalho B.P. de: Food security and hedonic behavior: a case study of São Tomé e Principe. Food Policy, Vol. 23, n³/4, pp. 263-275. Elsevier Science Ltd. Great Britain 1998.

8. Carvalho B.P. de: International Journal on Food System Dynamics. 4(2), 2013, 88-105. University of Bonn. Germany 2013.

9. Carvalho B.P. de, e Miguel Monteiro (2012): Segurança Alimentar em Cabo Verde: Contribuições da ANSA nos últimos Dez Anos (2002-2012). Revista Internacional em Língua Portuguesa. III - serie, N. 25 de 2012. Associação das Universidades de Língua Portuguesa. Lisboa, pp. 91-114.

10. Carvalho B.P. de, Monteiro D. and Carvalho N.: Global challenges and local solutions: wine sector changes in Europe and in Portugal. IAMA, $19^{\text {th }}$ Annual World Forum and Symposium. Budapest, Hungary 2009.

11. Carvalho B.P. de: Modernização da Agricultura: Análise de 6 Culturas no Brasil. Master Thesis. ESALQ - University of S. Paulo. Brazil 1982.

12. Carvalho B.P. de: Segurança Alimentar, Qualidade de Vida e Desenvolvimento. Revista de Ciências Agrárias, XXVIII (1), pp. 148-158, Sociedade de Ciências Agrárias de Portugal. Lisboa 2005.

13. Carvalho B.P. de: Regulatory development in food security: Republica de Cabo Verde. World Bank supported study for the Prime Minister Office. Cabo Verde 2000.

14. Comission on Human Security. Human Security Now. Report to the United Nations from an independent comission launched at the 2000 UN Millennium Summit, an initiative from Japan Government. New York 2003. 
15. Espirito Santo, Severino and B.P. de Carvalho: Food Consumption, Food Chains and Market Evolution in São Tomé e Principe. $6^{\text {th }}$ International European Forum (Igls Forum). Austria. Organization of the International Center for Food Chain and Network Research. University of Bonn 2012.

16. Fachinello A.L.: Cadeias Agropecuárias e Desenvolvimento Económico. I Simpósio Internacional de Agronegócio da Comunidade de Países de Língua Portuguesa. Santa Maria, Rio Grande do Sul, Brasil 2014.

17. FAO, Food and Agriculture Organization of the United Nations, 2009 to 2012.

18. FAOSTAT 2012 and 2013.On line data bases.

19. FAO (2009-12). The State of Food and Agriculture. Rome.

20. FAO (2010-12). The State of Food Insecurity in the World. Rome.

21. Hayami, Y. e V. Ruttan: Agricultural development: an internacional perspective. The John Hopkins Univesity Press. Baltimore and London 1985.

22. Krüger J.J.: Productivity and structural change: a review of the literature. Journal of Economic Surveys, 22(2): pp. 330-363. Blackwell Publishing Ltd. Oxford 2008.

23. Lee J.D., Seogwon H. and T. Kim: The measurement of consumption efficiency. Considering the Discrete Choice of Consumers. Journal of Productivity Analysis, 23, 65-84, Springer Science+Business Media, Inc. The Netherlands 2005.

24. Mellor J.W. and B.F. Johnston: The world food equation: interrelationships among development, employment and food consumption. Journal of Economic Literature, vol. 22, 1984, 531-574.

25. Ministério da Agricultura: Anuário Agrícola. Informação de Mercados (2012 e outros). Gabinete de Planeamento e Políticas. Lisboa MAMOT.

26. Ministério da Saude: Programa Nacional para a Promoção da Alimentação Saudável. Direcção Geral da Saude. Lisboa 2013.

27. Omta S.W.F. and S.J. Hoenen: Three fundamental perspectives on supply chain management. In Food Value Chain Network in the $21^{\text {st }}$ Century: International Challenges and Opportunities. Julian Brizand Isabel de Felipe org. Editorial Agrícola Espanhola, S.A. Madrid 2012.

28. ONU - Commission on Human Security. Human Security Now. New York 2003.

29. Peterson W.: Principles of economics. Micro. Six Edition IRWIN, Homewood, Illnois, USA 1986.

30. Rosa Eugénio: Os Grupos Económicos e o Desenvolvimento em Portugal no contexto da Globalização. Tese de Doutorado. ISEG. Universidade de Lisboa 2012.

31. Simon G.: Food security: definition, four dimensions, history. University of Roma. Faculty of Economics/Master in Human Development and Food Security 2012.

32. Williamson O.E.: The new institutional economics: taking stock, looking ahead. Journal of Economic Literature, Vol 38, N. 3, 2000, 595-613.

33. World Bank data bases.Worldwide Governance Indicators. Access on http://info.worldbank.org/governance/wgi/sc_chart.asp.(2013.02.05).

Słowa kluczowe: regulations, Markets, economic efficiency, sustainable, development, Food, Fruit, structural changes 